\title{
Ocean surface warming in Krossfjorden, Svalbard, during the last 60 years
}

\author{
Harikrishnan Guruvayoorappan ${ }^{1,2,3}$ (1) $\cdot$ Arto Miettinen ${ }^{1,4} \cdot$ Dmitry V. Divine $^{1} \cdot$ Matthias Moros $^{5} \cdot$ Lisa C. Orme $^{6}$. \\ Rahul Mohan ${ }^{2}$
}

Received: 27 June 2019 / Accepted: 22 November 2019

(c) Springer Nature Switzerland AG 2019, corrected publication 2019

\begin{abstract}
A high-resolution marine sediment core NP16-Kro1-MCB from Krossfjorden, Western Svalbard is studied to investigate changes in sea surface conditions in the fjord during the last 60 years (1953-2014). The diatom-based reconstruction of August sea surface temperature (aSST) demonstrates a clear warming trend of $0.6{ }^{\circ} \mathrm{C}$ through the record. As inferred from Marginal Ice Zone (MIZ) diatoms, surface warming occurs in parallel with a decline in sea ice extent (SIE) during recent decades. Factor analysis identified variations in diatom assemblages representing different water masses, showing a dominance of Arctic water diatoms throughout the period and decadal variations in the sea ice assemblage during periods of peak sea ice extent. The strong dominance of Arctic water diatoms along with increasing aSST suggest prolonged open-water conditions and increased sea ice melting in the region throughout the observed period. The reconstructed ocean surface changes are in line with the background warming occurring over the Arctic region. A comparison with instrumental records from neighboring regions supports the quality of the reconstructions, including the average reconstructed aSST and the magnitude of the warming trend. We suggest that increased $\mathrm{CO}_{2}$ forcing together with ocean-atmospheric interaction have caused the increasing SST trend and decreasing sea ice presence in Krossfjorden rather than an increasing influence from Atlantic Water, which has amplified changes in many regions of Svalbard.
\end{abstract}

Keywords Sea surface temperature $\cdot$ Sea ice $\cdot$ Diatoms $\cdot$ Reconstruction $\cdot$ Krossfjorden $\cdot$ Svalbard

Electronic supplementary material The online version of this article (https://doi.org/10.1007/s41063-019-00071-x) contains supplementary material, which is available to authorized users.

Harikrishnan Guruvayoorappan

g.harikrishnan91@gmail.com

1 Norwegian Polar Institute, Fram Centre, 9296 Troms $\varnothing$, Norway

2 National Centre for Polar and Ocean Research, Vasco da Gama, Goa, India

3 Goa University, School of Earth, Ocean and Atmospheric Sciences (SEOAS), Taleigao Plateau 403206, Goa, India

4 Ecosystems and Environment Research Programme, University of Helsinki, P.O. Box 65, 00014 Helsinki, Finland

5 Leibniz Institute for Baltic Sea Research, Seestraße 15, 18119 Rostock, Germany

6 ICARUS, Department of Geography, Maynooth University, Mariavilla, Maynooth, Co. Kildare, Ireland

\section{Introduction}

In the context of recent climate change, understanding Arctic-wide warming is of utmost importance. Effects of global warming are most visible in the Arctic, manifested in the form of declining sea ice extent (SIE), increasing sea surface temperatures (SSTs) and atmospheric warming [45, 51]. The high sensitivity of the Arctic to climate change [25] and the amplification of warming by ice-albedo feedbacks [36], makes the Arctic a "hotspot" for climate change studies. Instrumental records of SST and SIE extend back 150 years at most and many regions within the Arctic have much shorter observational records. Thus, temporally constrained records of long-term climate variability in the Arctic would place recent warming in a long-term context and help to constrain climate models [45].

Within the Arctic Svalbard, and specifically its western continental margin, occupies a unique position, being located in the Fram Strait, which is the only deep connection of the Arctic basin with the Atlantic Ocean. Located in 
the seasonal sea ice zone, Svalbard is influenced by general atmospheric circulation variability and annual variations in light conditions, sea ice extent and ocean currents, making it a climatically sensitive area [60]. Atlantic Water (AW) is the main heat source towards the high latitudes and any variations in this inflow strongly influence the regional energy budget manifested as variations in regional SST, water column stratification, salinity and sea ice cover $[45,58]$. Svalbard is a heavily glaciated region, where $60 \%$ of the area is covered by glaciers [17]. The amplified retreat in glaciers has been evident in the last 30 years, as a part of late twentieth-early twenty-first century warming [44]. The rise in surface air temperature has resulted in a reduction in glaciated area and a rapid retreat of tidewater glaciers in Svalbard $[19,30,55]$. Recent changes in large-scale atmospheric patterns have resulted in an anomalous AW inflow from the West Spitsbergen Current (WSC) onto the West Spitsbergen Shelf (WSS) and into the fjords, even in the winter season, resulting in reduced sea ice formation and ice free waters around the west and north of Svalbard [9, 15, 42, 43, 48, 63]. The recent net surface radiation budget $\left(Q_{\text {net }}\right)(1992-2012)$ from Ny-Ålesund shows a total increase of $5.1 \mathrm{~W} / \mathrm{m}^{2}$ per decade; downward shortwave radiation $\left(\mathrm{SW}_{\text {down }}\right)$ has shown the largest increase in summer $\left(4.9 \mathrm{~W} / \mathrm{m}^{2} /\right.$ decade $)$, while upward shortwave radiation $\left(\mathrm{SW}_{\text {up }}\right)$ has shown a decrease of $-7.0 \mathrm{~W} / \mathrm{m}^{2} /$ decade (summer). Increasing $Q_{\text {net }}$ and $\mathrm{SW}_{\text {down }}$ radiation in summer has resulted in longer melt seasons (due to an increase in heat absorption by surface waters) and hence delayed sea ice formation, which coupled with the increase in upward longwave radiation $\left(\mathrm{LW}_{\mathrm{up}}\right)$ in winter has caused increasing air temperatures in Svalbard [36].

Along with these contemporary climatic studies, Svalbard has been the focus of paleoclimatic research including several studies based on analysis of marine sediments from the Western continental margin [11, 18, 27, 56-58, 66]. Most of these studies focused on long-term Holocene changes in paleoceanographic conditions of the region. In this study, we examine ocean surface conditions from Krossfjorden, in the western continental margin of Spitsbergen, Svalbard, spanning 60 years (1953-2014 CE). Using diatom microfossils, we generate the first diatom-based reconstructions for past ocean surface conditions from the western Svalbard fjord. Furthermore, the high temporal resolution of the derived records allows their direct comparison with recent instrumental observations for the area, bridging together two techniques for inferring ongoing and past climatic changes.

\section{Study area and oceanographic setting}

Krossfjorden is part of Kongsfjorden-Krossfjorden system $\left(78^{\circ} 40^{\prime}\right.$ and $77^{\circ} 30^{\prime} \mathrm{N}$ and $11^{\circ} 3^{\prime}$ and $13^{\circ} 6^{\prime} \mathrm{E}$ ), located on the west Spitsbergen continental margin (Fig. 1).
Krossfjorden spans up to $30 \mathrm{~km}$ in length and is $3-6 \mathrm{~km}$ wide. The inner part of the fjord is divided into Lillehookfjorden and Mollerfjorden by Cape Kong Haakons Halvøya. The head of the fjords are bound by tidewater glaciers Lillehookbreen and five other calving glaciers along the eastern coast [60]. Being located along the west Spitsbergen coast, warm Atlantic water advection is prevalent through the year-round influx of the West Spitsbergen Current (WSC), which is the northward extension of the North Atlantic Current (NAC). The fjord also receives water from the East Spitsbergen Current (ESC), which passes from the Arctic Ocean around the Eastern coast of Svalbard, and finally enters the fjord as a coastal current $[11,60]$.

Based on the temperature and salinity profiles, three major water masses can be defined within the fjord system. Three such types of water masses can be observed in the fjord, namely External, Internal and Mixed water masses. External water masses include Atlantic Water (AW) and Arctic Water (ArW). Both these water masses converge in the West Spitsbergen Shelf forming mixed water masses. These include Transformed Atlantic Water (TAW) and Intermediate Water. Internal water masses include Winter Cooled Water (WCW), Local Water (LW) and Surface Water (SW). While WCW and LW are formed during sea ice formation, $\mathrm{SW}$ is formed during late spring to early summer $[9,60]$. In the Kongsforden-Krossfjorden system, the presence of active glacier strongly influences mixing processes, as freshwater runoff from the glacier affects the surface waters. Earlier studies from the region show that surface water in glacier fronts, especially in Krossfjorden, remain relatively fresh with sea ice melting and stratification, along with little Atlantic Water influence [50]. Sea ice conditions in the Kongsfjorden-Krossfjorden system show a distinct seasonal pattern. Young ice is the dominant winter ice type, later dominated by first year fast ice in early spring. A combination of fast ice and drift ice along with icebergs, growlers and bergy bits of fresh ice is the typical situation once fast ice starts to disappear in late spring to early summer [60]. Freezing processes in the inner fjord remove freshwater from surface waters during the winter and supply freshwater during melting in the summer. The proximity of the glacier also has a local atmospheric influence, as wind directions follow downfjord patterns in the winter season and up-fjord patterns during the summer season.

Settling of fine-grained sediments from meltwater plumes and ice rafting are the dominant processes of sediment supply to glaciated fjords today [12-14, 22, 24, 37, 59]. Previous work on the Kongsfjorden-Krossfjorden system [33] shows that the region is characterized by bi-modal or trimodal grain size distributions. The meltwater plumes show the dominance of suspension settling, with modes at ca. $2-3 \mu \mathrm{m}$ and $10-20 \mu \mathrm{m}$ and a secondary mode at $>100 \mu \mathrm{m}$ 
Fig. 1 a Map of the Svalbard region highlighting the study area (rectangle), and major features of ocean surface circulations, North Atlantic Current (NAC: red) and East Spitsbergen Current (ESC: blue) (upper panel), location of Lomonsovfonna Ice core (denoted as a star) [64], $\mathbf{b}$ the location of the Krossfjorden core site is denoted as a red circle (lower panel) [64]
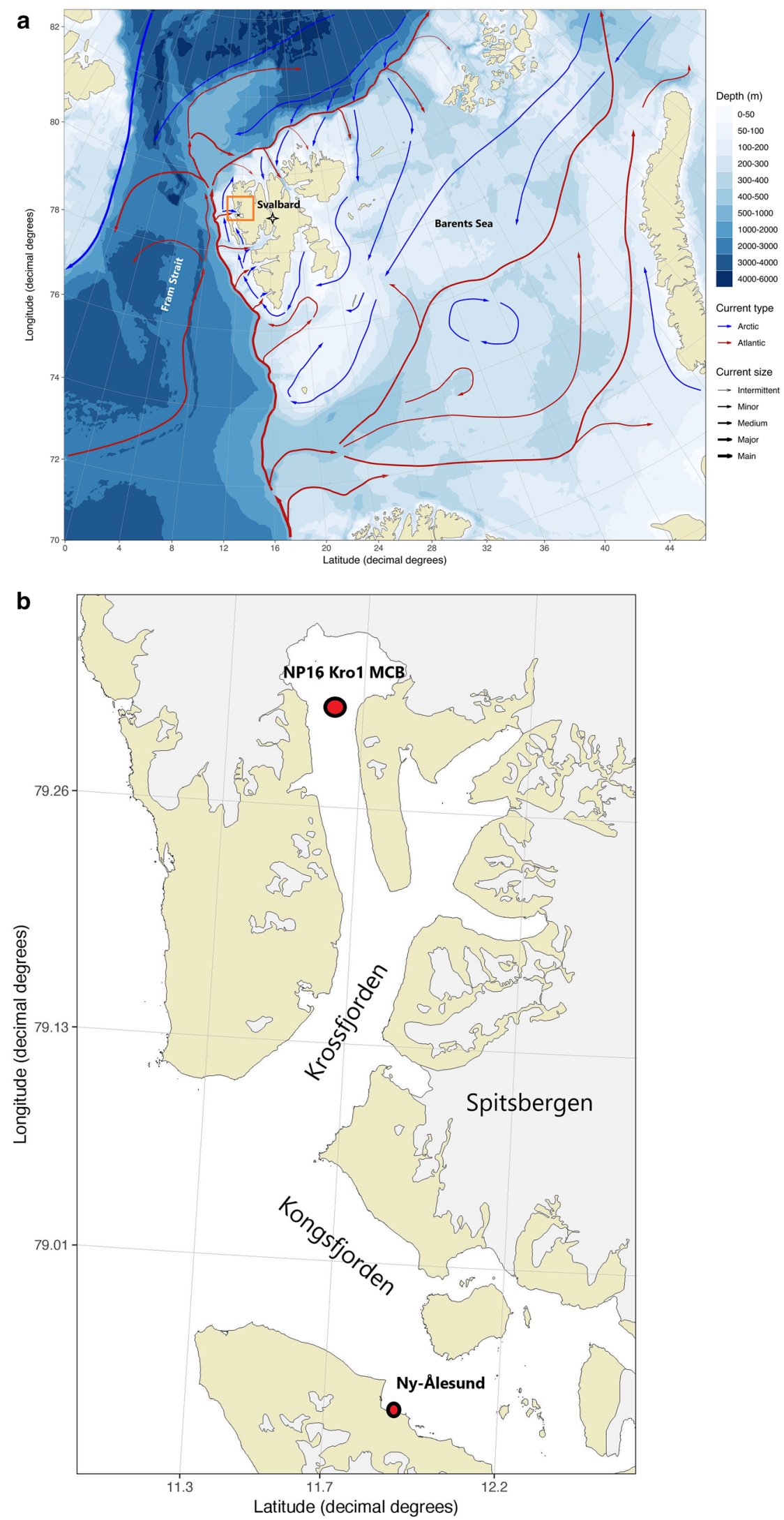
also known as IRD, which has a limited distribution in Krossfjorden [24].

The proximity to the glacier also limits the biomass production in the fjord system [50]. Phytoplankton spring blooms occurs in the Kongsfjorden-Krossfjorden system in May and the dominant diatom communities of the growth season include Thalassiosira spp., Chaetoceros spp., and Fragilariopsis spp. [20, 50]. Compared with near glacial sites, measurements of phytoplankton biomass ( $\mathrm{Chl} a$ ) from middle parts of Kongsfjorden and Krossfjorden show a massive spatial variation, as $\mathrm{Chl}$ is significantly lower in the glacier front sites where nanoplankton dominates the spring bloom [50].

\section{Materials and methods}

The core NP16-Kro1-MCB was recovered from the inner part of Krossfjorden $\left(79^{\circ} 17.76^{\prime} \mathrm{N}, 011^{\circ} 36.48^{\prime} \mathrm{E}\right)$ from a water depth of $105.6 \mathrm{~m}$ using a multi-corer during the NPI MOSJ-ICE 2016 cruise in July 2016 from R/V Lance. The $32 \mathrm{~cm}$ long core was subsampled every $1 \mathrm{~cm}$, providing in total 32 samples for diatom and grain size analyses. Grain size distribution analysis was done using the standard wet sieving procedure and the sediment samples were grouped into three major fractions: sand $(>63 \mu \mathrm{m})$, silt $(8-63 \mu \mathrm{m})$ and clay $(<8 \mu \mathrm{m})$.

\section{Chronology}

The age depth model of the core is based on two anthropogenic ${ }^{137} \mathrm{Cs}$ time markers from depths $22.5 \mathrm{~cm}, 32.5 \mathrm{~cm}$ and the age of the core top (Fig. 2). The values for ${ }^{137} \mathrm{Cs}$ accumulation in the sediments ranged from 1.1 to $13.3 \mathrm{~Bq} / \mathrm{kg}$ and the activity maximum was detected at $22.5 \mathrm{~cm}$. Since the ${ }^{137} \mathrm{Cs}$ activity was still above the detection limit in the lowermost core sample at $31.5 \mathrm{~cm}$ depth (Supplementary data, Table 1, Supplementary Figure 1), we by extrapolation found the onset of the ${ }^{137} \mathrm{Cs}$ contamination to be associated with a depth of $32.5 \mathrm{~cm}$ at the core location. This depth was, therefore, associated with the timing of first occurrence of ${ }^{137} \mathrm{Cs}$ and hence can be attributed to the sediments deposited after 1952. This corresponds to the period of early atmospheric nuclear and thermonuclear tests. A pronounced ${ }^{137} \mathrm{Cs}$ activity maximum at $22.5 \mathrm{~cm}$ was attributed to the $1963{ }^{137} \mathrm{Cs}$ maximum reference level [21] also detected in Svalbard ice cores [49]. To account for the variability in sedimentation rate and a thickness of bulk sample used for the radionuclide analysis, the dates for both reference horizons were set to 1952(2) and 1963(2) where the number in parenthesis stands for the age of the standard deviation.

The age depth model for the core was developed with Bayesian technique OxCal 4.2 [7] using a Poisson deposition

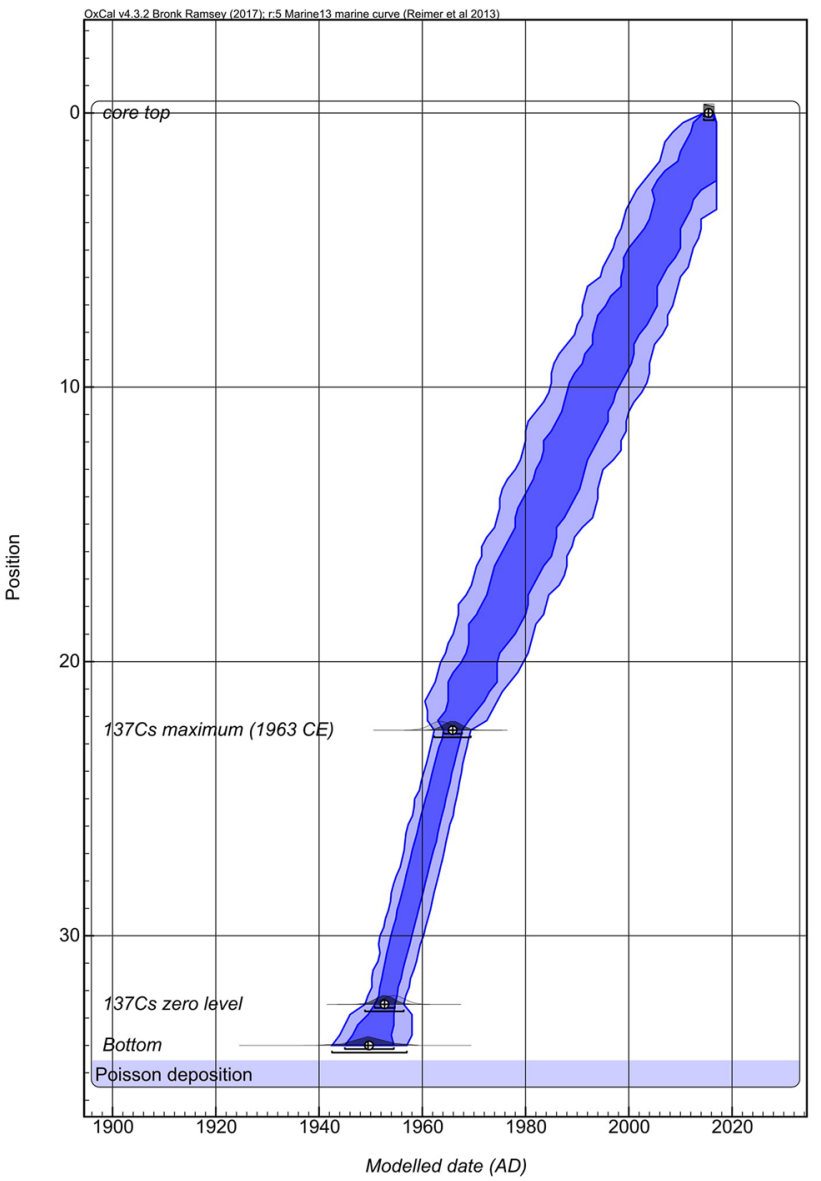

Fig. 2 Age depth model of the Krossfjorden core NP16-Kro1-MCB. The model is based on two ${ }^{137} \mathrm{Cs}$ time markers from depths $32.5 \mathrm{~cm}$ and $22.5 \mathrm{~cm}$. Dark and light blue envelops outline the $68 \%$ and $95 \%$ probability density ranges for the depth age model, corresponding approximately to a one and two age standard deviations, respectively. Light gray shows the probability distributions (likelihoods) for single dates; their marginal modeled posterior distributions which take into account the constructed depth age model are shown in dark gray. The median modeled ages of the time markers used are highlighted as circles with crosshairs

model with a model parameter $k=2$, which corresponds to possible sedimentation rate changes on an interannual time scale [6]. Since the core top had visually undisturbed sediment, it has been associated with the year of core recovery, although to allow for variability in the sediment accumulation rate (and taking the average sediment accumulation rate (SAR) of $0.5 \mathrm{~cm} /$ year into account), the age of the topmost sample of the core was set to U[2014,2016], with U standing for the uniform probability distribution function.

\section{Diatom analysis}

Altogether 32 samples were analyzed for diatoms from the core. Preparations of diatom samples include removal of carbonates, organic matter and residual acids by chemical 
treatment [31]. Microscopic diatom counting and identification was done using a Leica Orthoplan microscope with $1000 \times$ magnification. The procedure for identification and counting of diatoms were done as described by Schrader and Gersonde [54] with 300 diatoms frustules counted per sample, with Chaetoceros resting spores excluded because of their low sensitivity to SST and dominance over diatom assemblages possibly biasing the reconstructions [32].

\section{SST reconstruction}

The abundant diversity of diatoms and their good analogue to modern water masses make them excellent proxies for paleoceanographic reconstructions [38]. While many records of quantitative diatom-based reconstructions for past ocean conditions exist for the subpolar North Atlantic [1-3, 11, 28, 29, 39, 40], the records from high Arctic fjords are really sparse [45].

For this study, a diatom calibration dataset, consisting of 183 surface sediment samples from the North Atlantic, Nordic seas, Baffin Bay and Labrador Sea with 52 diatom species [40], was utilized to convert the downcore diatom assemblages to estimates of August SST using the Weighted Averaging Partial Least Squares (WA-PLS) technique [61]. WA-PLS is a unimodal-based equivalent for multiple linear regression wherein a diatom species has an optimal abundance along with the environmental gradient being investigated [4, 38, 46, 61]. Compared with other quantitative paleotemperature reconstruction techniques, WA-PLS has numerous advantages like the capability to work with large datasets (in terms of species and sample numbers), handling numerous zero abundant values and a generally lower RMSEP. For the diatom-based SST reconstructions in the North Atlantic region, the best statistical fit between observed SST and estimated SST through the temperature range of modern calibration data $[4,38]$ was achieved for the summer temperatures, more specifically August SST [3, 40], which we used in this study. Furthermore, the skills of this method were thoroughly tested with a large calibration dataset to demonstrate a strong sensitivity to SST and a large effective temperature range $\left(0-20^{\circ} \mathrm{C}\right)$ of the derived transfer function, which allows skillful reconstructions in a broad range from cold periods (e.g. Younger Dryas and Little Ice Age) to warm climate conditions (e.g. Holocene Climate Optimum and Modern warming) [38].

The two-component WA-PLS transfer function has a root mean square prediction error (RMSEP) of $1.14{ }^{\circ} \mathrm{C}$ and a coefficient of determination between observed and inferred values $\left(r^{2}\right)$ of 0.92 . H-block cross-validation was used to estimate a prediction error so that samples closer than a cutoff distance (h) from the target sample were excluded from the prediction contribution in the sample [5, 62].
Presence of sea ice-associated diatoms has been used for qualitative reconstruction of sea ice in many previous studies $[1,32]$. The sea ice-related species, or so called "Sea Ice assemblage" used in previous studies include Fragilariopsis oceanica, Fragilariopsis cylindrus, Porosira glacialis, Rhizosolenia hebetata, Thalassiosira hyalina, Thalassiosira gravida/antarctica spore, Thalassiosira nordenskioeldii and Bacterosira fragilis [1, 29, 32]. The occurrence of these sea ice-related species was used as an argument for cold conditions. However, recent diatom studies (based on statistical data analyses and related sea ice biology of these species) show that many of these sea ice species can indicate sea ice melt, i.e. relatively warm conditions of a seasonal ice zone $[45,46]$. For this reason, "Sea Ice assemblage" was recently renamed as "Marginal Ice Zone assemblage" (MIZ), as the relative abundance of MIZ diatom taxa can be used to qualitatively reconstruct sea-ice variability and glacier-melting events $[45,46]$. These MIZ species are sea ice associated occurring both in sea ice and in open-water phytoplankton of the marginal ice zone [46].

In our study, the qualitative sea ice record is based on Marginal Ice Zone (MIZ) diatom assemblage constituting of three diatom species that indicate the presence of sea ice in the region: Actinocyclus curvatulus, $P$. glacialis and $F$. oceanica [46]. The percentage contribution of these species to the assemblage counted for each sample was used to estimate the presence of sea ice through the core. These species favor cold, fresh water usually associated with melting sea ice and bloom over the melt water layer, and thus they are usually found near the marginal sea ice regions which melt during the summer season [8, 34, 65].

\section{Factor analysis}

Q-mode factor analysis was performed on the analyzed dataset to understand past oceanographic conditions at the sampling site on the basis of prevalent surface water masses. Previous studies by Andersen et al. [1,2] and most recently Oksman et al. [46] have demonstrated a close association between the spatial distribution of factors (aka "typical assemblages") and modern regional oceanographic settings in the study area, thereby linking composition of diatom taxa in the calibration (surface sediment) data set with the spatial distribution of prevalent water masses. Q-mode factor analysis (when applied to the modern diatom calibration dataset) reveals eight major diatom assemblages or "factors" associated with the following major oceanic water masses [2, 45-47]: Greenland Arctic water assemblage (factor 1), North Atlantic current assemblage (factor 2), Sub-Arctic water assemblage (factor 3), Norwegian-Atlantic current assemblage (factor 4), Marginal Ice Zone (MIZ) assemblage (factor 5), Arctic water assemblage (factor 6), East-West Greenland Current (factor 7) and Transitional water (factor 
8 ), that together represent about $95 \%$ total variance. Changes in the abundance of these assemblages, manifested via changes in the respective factor loadings through time, will reflect changes in dominance of different water masses at the study site, also providing additional support to the estimated aSST [4]. Note that Sea Ice assemblage, which used to be called Factor 5 has now been renamed as the Marginal Ice Zone (MIZ) assemblage (as per Miettinen et al. [38] and Oksman et al. [46]), as many sea ice diatoms have now been revealed as indicators of sea ice and glacier melting rather than perennial sea ice cover.

\section{Results}

\section{Sediment structure}

The sediment consists of gray silty clay (approximately $>90 \%)$, sand (5\%) and very coarse sand (0-2\%). The grain size fractions indicate a stable depositional environment and a very high sedimentation rate of about $0.5 \mathrm{~cm}$ year $^{-1}$ on average at the core site for the examined time interval 1953-2014. The relative composition of three fractions is generally stable except for two short periods with increases in the coarser sediment fraction from 1959 to 1960 and from 1996 to 2001 (Fig. 3).

\section{Diatom assemblages in NP16-Kro1-MCB core}

A total of 28 diatom species were observed in the core. Relative abundances of 16 species, including major species and those with higher indicator values for environmental parameters (SST, sea ice) are shown in Fig. 4. The diatom species assemblage is dominated by Arctic water diatom species and highly variable sea ice-associated diatoms. The general diatom assemblage throughout the core shows maximum percentages of the sub-Arctic cold-water species Thalassiosira antarctica var. borealis resting spore, which increased in abundance through the record. Other Arctic water species such as Bacterosira bathyomphyla, Fragilariopsis cylindrus and $T$. gravida also show that maximum abundances were reached towards the present day. Fragilariopsis cylindrus is a common species with high abundances through Fram Strait, and Nares Strait in North Water Polynya. Bacteriosira bathyomphyla is found mostly offshore of South West Svalbard and in the Fram Strait, East Greenland Current, Western
Fig. 3 Result of grain size distribution along the core depth. In the diagram, blue bars represent $\%$ of clay and silt, orange bars represent $\%$ of sand and green bars represent $\%$ of very coarse sand

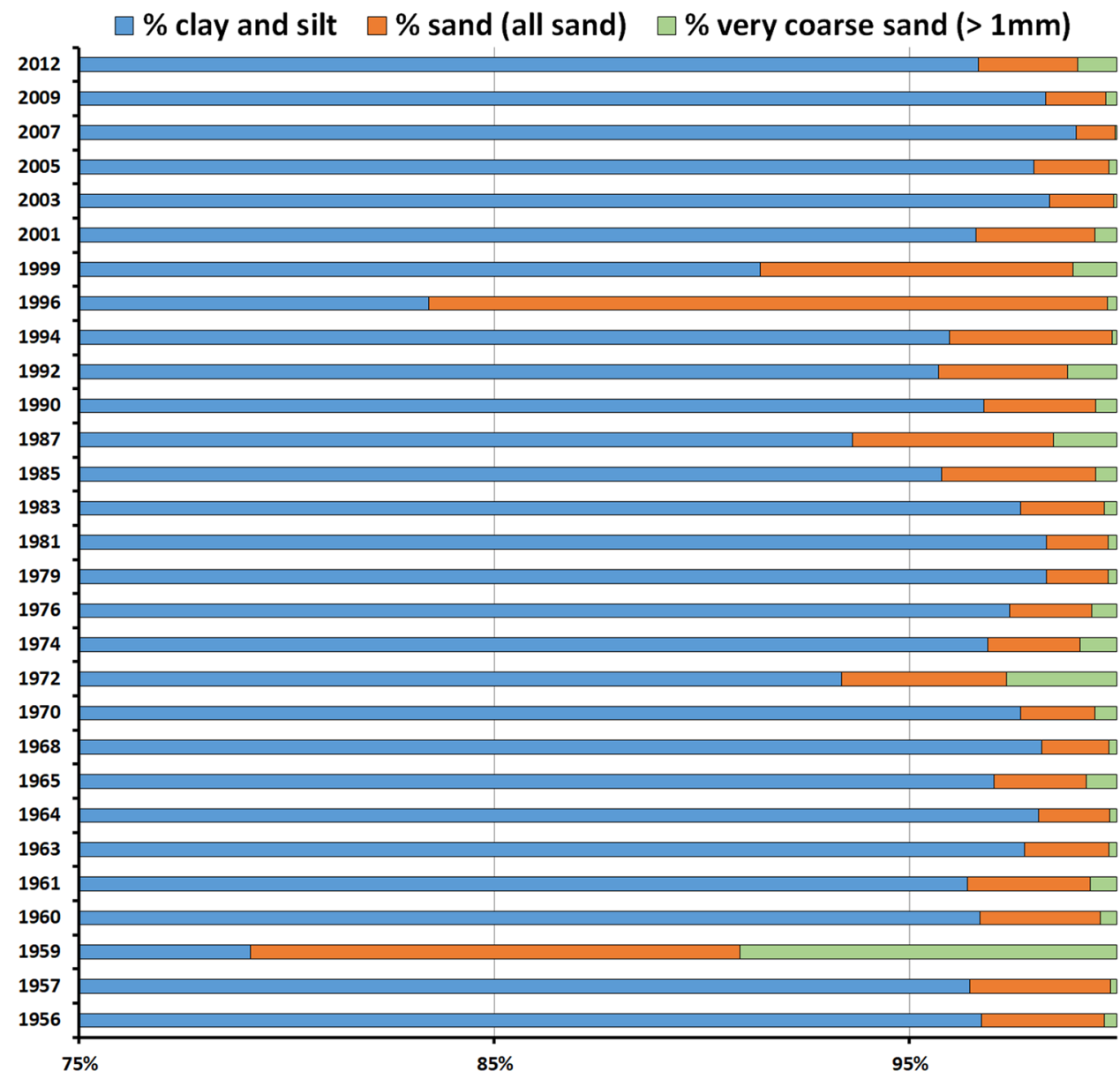




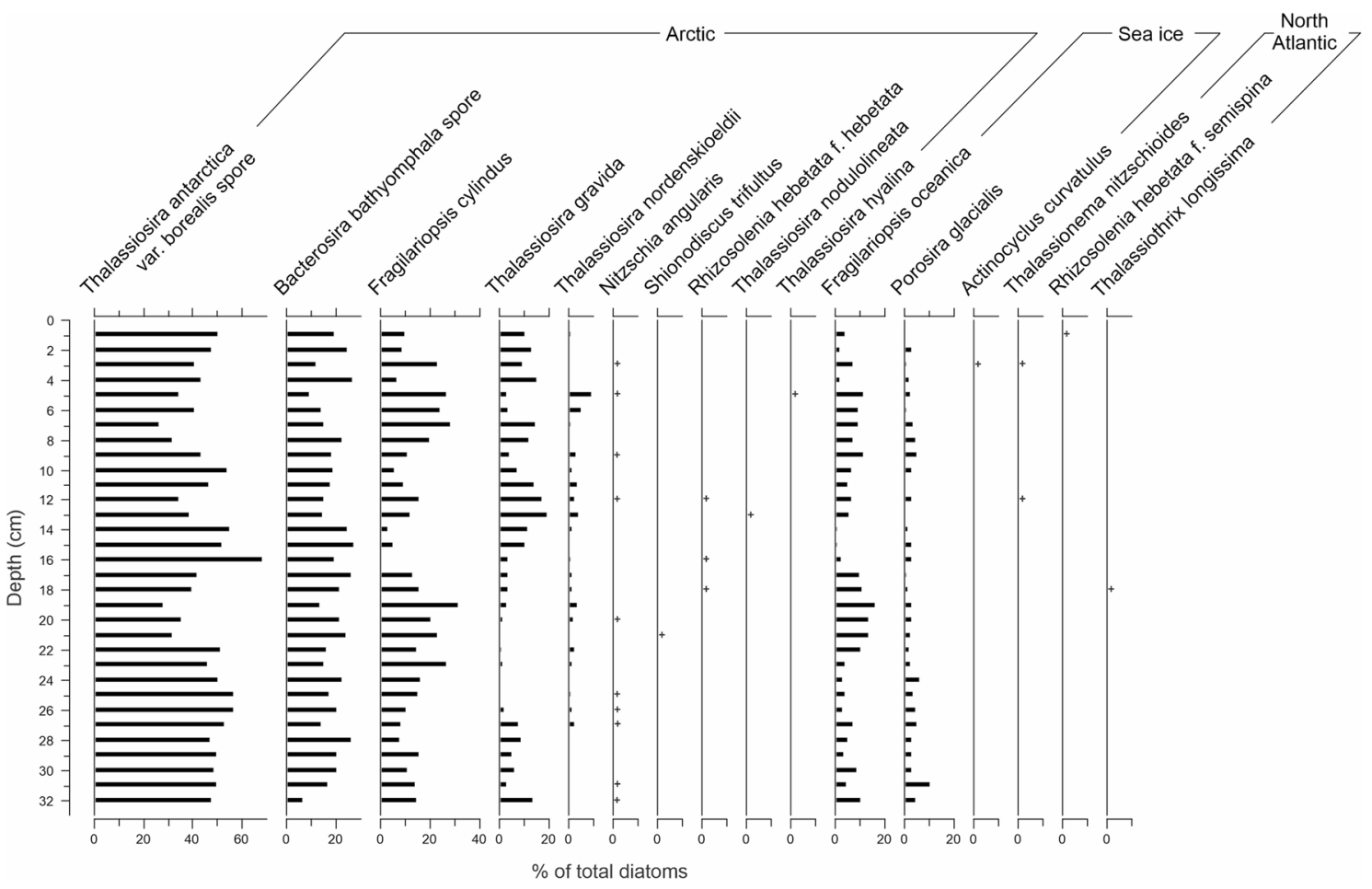

Fig. 4 Relative abundance of 16 most common diatom species of core NP16-Kro1-MCB. The core represents years from 1953 to 2014

Baffin Bay and Northern Labrador Sea. Thalassiosira grav$i d a$ is found from Arctic to near temperate regions and is common in the Labrador Sea, Jan Mayen Polar Current and East Icelandic Current [46]. The MIZ diatoms F. oceanica, $P$. glacialis and $A$. curvatulus show variable abundances through the core, whilst $F$. oceanica is present throughout, the species abundance peaks at $32-26 \mathrm{~cm}, 21-16 \mathrm{~cm}$ and $12-5 \mathrm{~cm}$, which correspond to the periods of 1953-1955, 1960-1964, 1974-1979 and 1994-2005, respectively. The maximum abundance of $F$. oceanica through the aforementioned years also corresponds to an increase in abundance of P. glacialis, another sea ice-associated diatom.

\section{Quantitative SST reconstruction}

The quantitative SST reconstruction for 1953-2014 shows an average August SST of $4.5^{\circ} \mathrm{C}$ ranging from 4.3 to $5.2^{\circ} \mathrm{C}$. The reconstruction shows an increasing mean aSST trend of $0.6^{\circ} \mathrm{C}$ through the record (Fig. 5). The highest reconstructed aSST can be associated with the periods 1987-1990 and 1999-2007; however, it is noteworthy that all given age estimates are approximate given chronological uncertainties.

\section{Qualitative sea ice reconstruction}

Percentages of MIZ diatoms show a decreasing trend, with a maximum fraction of species $F$. oceanica and $P$. glacialis registered from 1968 to 1979 (Fig. 5). The lowest percentages of MIZ diatoms occur at 1981-1987 and 2007-2014, which suggest that these periods were associated with a shorter sea ice cover season (seasonal sea ice presence) in the fjord.

\section{Factor analysis of diatom assemblages}

The factor analysis shows relatively high communalities (varying within 0.6-0.9) for the downcore assemblages, indicating that there is a good agreement between the reconstructed and modern assemblages in the calibration dataset, and hence providing additional confidence to the estimated SST. The two diatom assemblages linked with factor 6 (Arctic Water) and factor 5 (Marginal Ice Zone) show high loadings throughout the core and contribute to most of the variance in the analyzed dataset.

The Arctic water assemblage has dominated the study site throughout the studied period, with highest values at 1953-1974 and 1981-1996, and an increase from 2003 to 2014. In the study region (North Atlantic realm), the Arctic water assemblage is associated with mixed water masses located between warmer and saline waters of the NorwegianAtlantic current and West Spitsbergen current and cold fresh waters of the Arctic outflow. The MIZ assemblage shows the next highest communalities with generally decreasing values and weak decreasing trend from 1953 to 2014. 

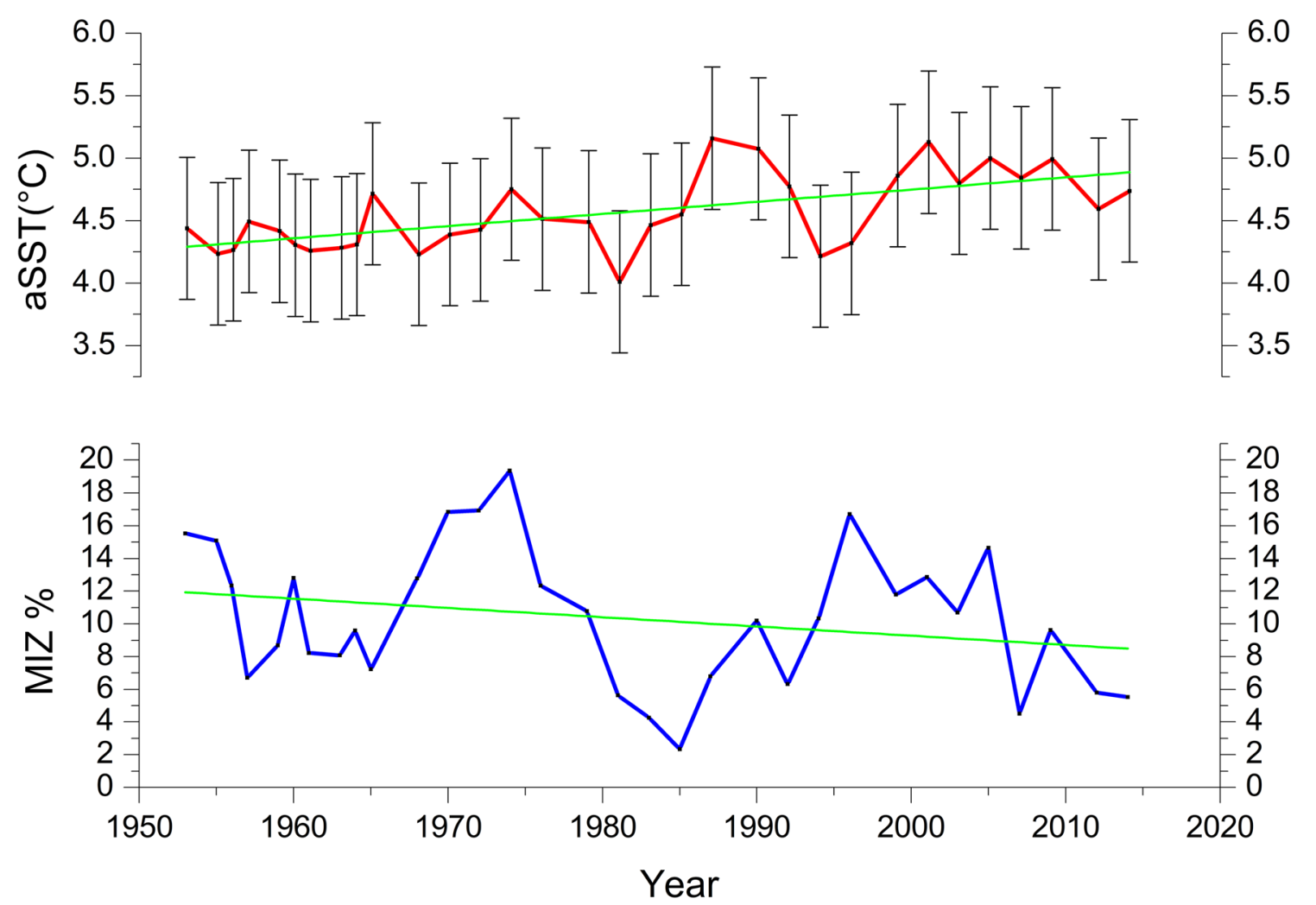

Fig. 5 Diatom-based aSST (top) and sea ice (bottom) reconstructions for 1953-2014. The bars indicate confidence interval for aSST. Green lines highlight the respective statistical linear fits to the data

\section{Discussion}

The aSST reconstruction and qualitative reconstruction of sea ice presence for the last 60 years are the first diatom proxy-based records for the region. The reconstructed aSST increase of $0.6{ }^{\circ} \mathrm{C}$ from between 1953 and 2014, and the decreasing MIZ\% for the same time period clearly indicates the warming of the ocean surface and diminishing ice season duration in Krossfjorden since the 1950s. Based on the abundance of Arctic water diatoms, we suggest that the open-water period is prolonged throughout the studied interval, with decreasing sea ice presence in the fjord. Only two periods, 1953-1956 and 1968-1976 show maximum MIZ\% which indicate increased sea ice presence at the core site.

The topmost part of the reconstructed aSST was compared to the modern temperature data obtained from the CTD measurements of the same cruise (conducted in July 2016) at the core location in Krossfjorden (CTD profile attached as Supplementary material). The reconstructed aSST showed a value of $4.7^{\circ} \mathrm{C}$ for $2014-2016$, the date assigned for the core top, and the modern SST from the location showed a very similar temperature range, from 3.2 to $4.2{ }^{\circ} \mathrm{C}$ in the uppermost $20 \mathrm{~m}$ of the water column. aSST also shows similar values compared with Kongsfjorden SST's whose modern value ranges from 6 to $8{ }^{\circ} \mathrm{C}$ (Olga Pavlova personal. comm.).
The reconstructed aSST and sea ice from Krossfjorden was compared with summer SST (Fig. 7b) and April sea ice extent records from Fram Strait (Fig. 7h) in the west coast of Svalbard. The observed Fram Strait SST record starts from 1926, while continuous observational data exists only from 1979 [52] (Paul Dodd personal comm.). The observed general warming trend of SSTs from Fram Strait reflects very well the reconstructed aSST in Krossfjorden. Likewise, peak warming periods observed in the Fram Strait record at 1987-1990 and 2001-2005 and colder periods at 1981-1985 and 1992-1995 correspond with the warmer and colder periods in the aSST reconstruction. The sea ice extent in Fram Strait measured by satellite-based observations since 1979 (MOSJ-ICE reports) [52] (Paul Dodd personal comm.) and the reconstructed sea ice extent data show a decreasing trend since 1979. The relatively high MIZ\% in Krossfjorden coincides with the Fram Strait sea ice extent maxima from 1996 to 2005 and both show a decreasing trend following this period. Furthermore, the April Greenland Sea ice anomaly records from 1950 to 2002 clearly show a decreasing trend (Fig. 7g) [10] again reflecting the decreasing trend in Krossfjorden MIZ\% over this period. Over decadal timescales, the high MIZ\% at 1950-1970 and 1996-2005 also coincide with positive ice anomalies in the Greenland Sea [10]. The higher percentages of MIZ diatoms during 1950-1970 can 
be associated with the relatively cooler period in Svalbard during the 1950-1970's (Fig. 7d), indicating higher sea ice presence in the region [26] (Fig. 7).

Previous studies from the West Spitsbergen fjords suggest several mechanisms influencing the SST and sea ice extent variability in the region and the observed multidecadal warming. The most important factor influencing the fjords of Svalbard is found to be the enhanced subsurface Atlantic Water advection through the Fram Strait and Barents Sea [9, $20,41,42,48]$. In our work, the factor analysis of diatom assemblages for different water masses show low Atlantic water communities, whereas the Arctic water assemblage is consistently the most abundant throughout the record.
The Atlantic species communities do not rise despite the warming trend of surface waters, suggesting other factors were behind the warming; however, it can be observed that there is an increase in Arctic water assemblages associated with mixed water masses and subsequent recession of MIZ diatoms (Fig. 6), indicating a slow northward retreat of the MIZ and associated frontal area.

We hypothesize that ocean-atmosphere interactions may have been more important for the warming of surface water than Atlantic water inflow in Krossfjorden. When comparing the aSST and sea ice data from Krossfjorden, with the summer Surface Air Temperature (SAT) records obtained from Longyearbyen airport, the records
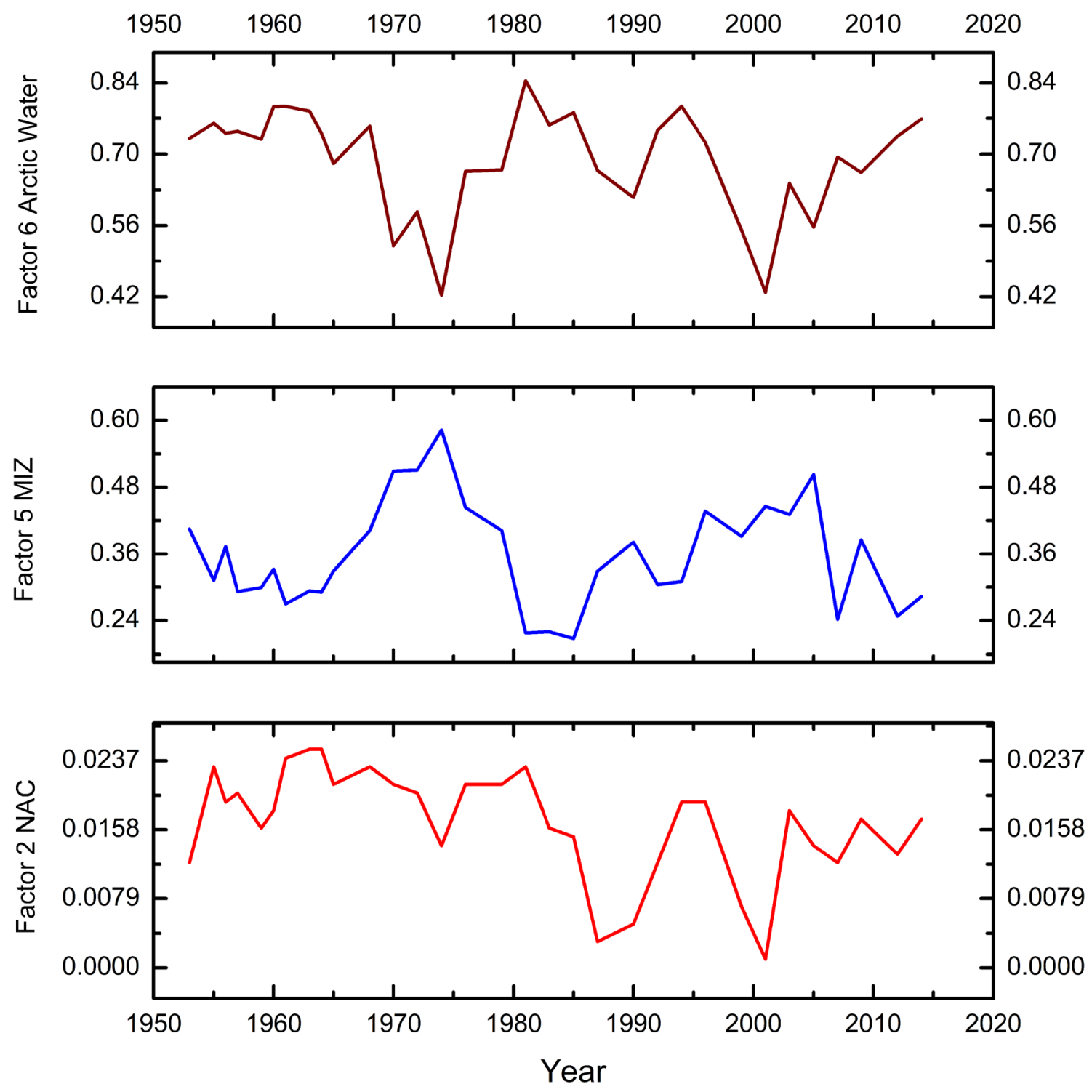

Fig. 6 Results of Q-mode factor analysis showing variability of factor loadings for three factors with highest loadings in the observed fossil diatom sequence. Top Factor 6, Arctic water assemblage, Middle Fac- tor 5, Marginal Ice Zone assemblage, Bottom Factor 2, North Atlantic Current assemblage 


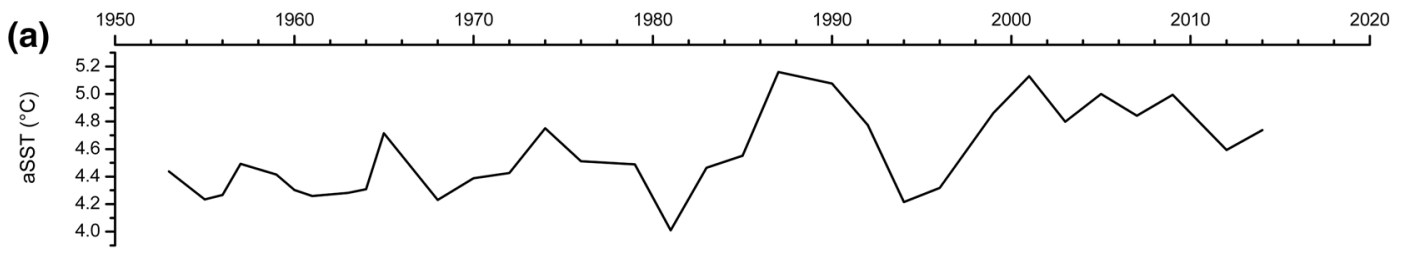

(b)

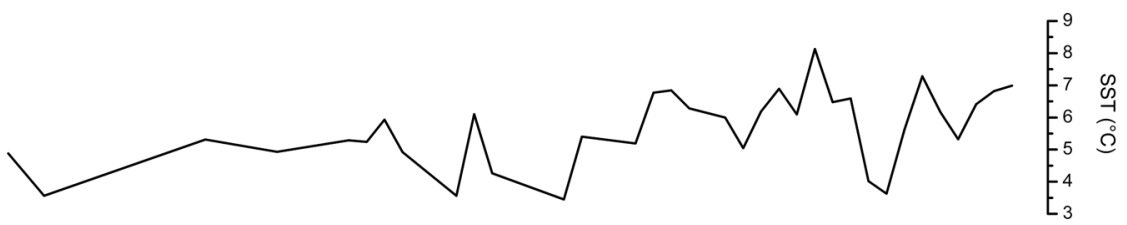

(c) 7.0

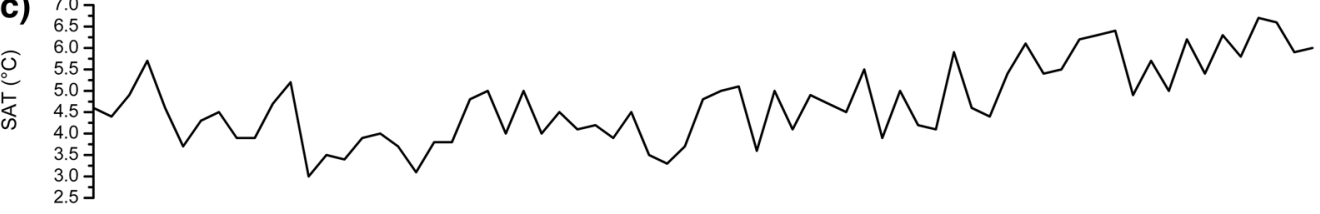

(d)
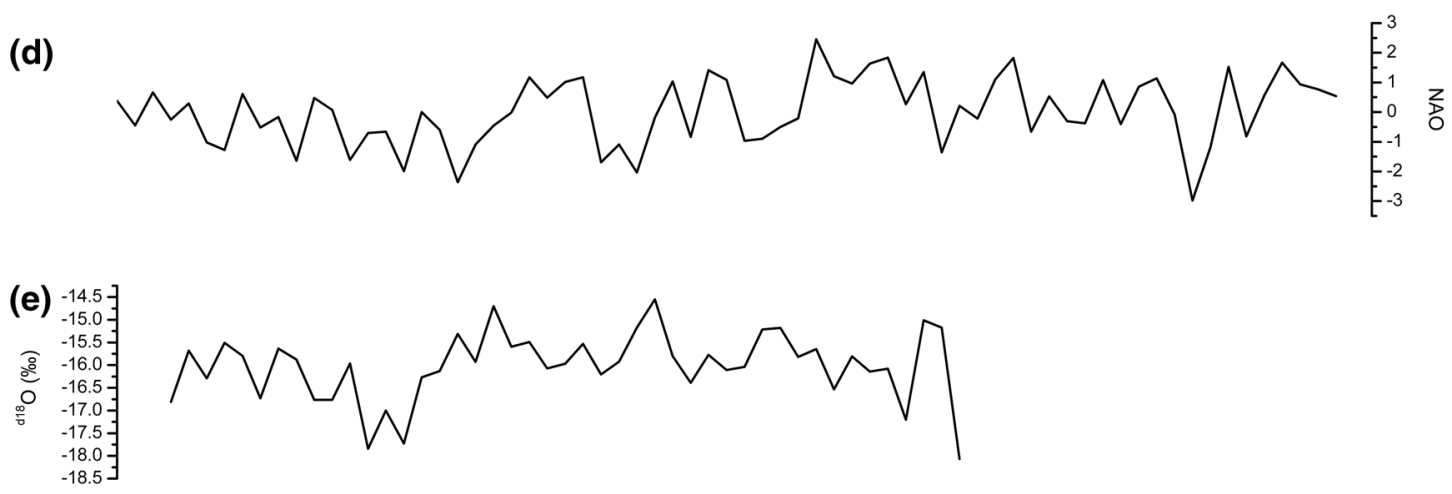

(f)

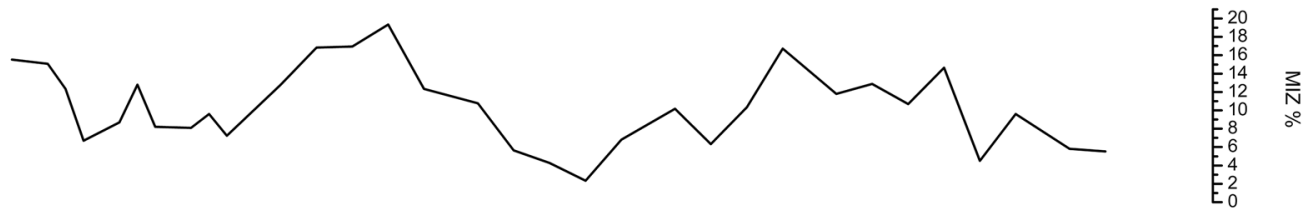

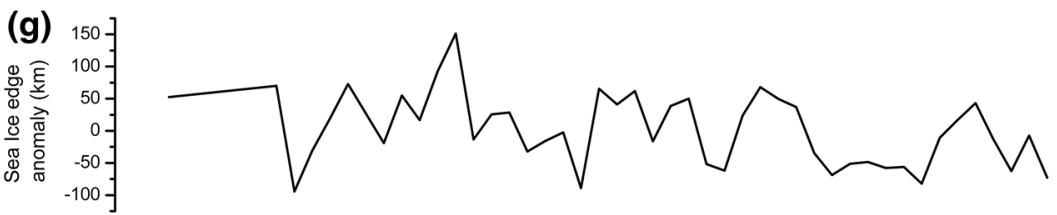

(h)

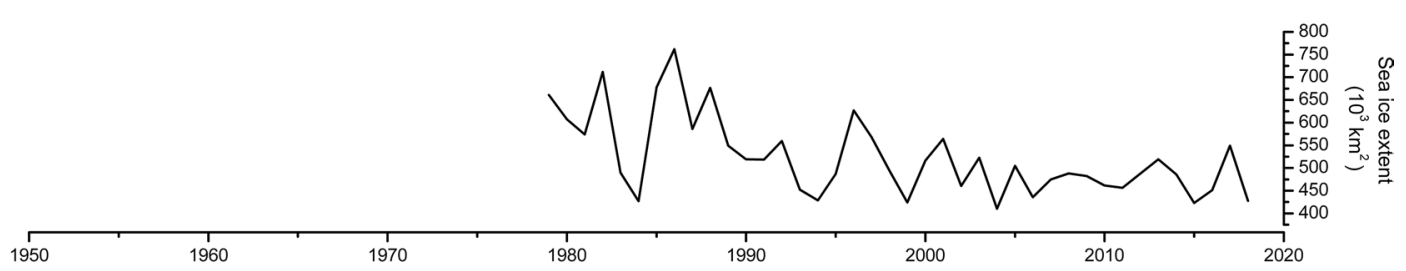

Fig. 7 Comparison between reconstructed parameters from core NP16-Kro1-MCB and selected records from Svalbard and its western margin. a Reconstructed aSST from the core NP16-Kro1-MCB, b fram strait SST record [44], c summer SAT records from Longyerbyean airport, Svalbard [44], $\mathbf{d ~ d ~}{ }^{18} \mathrm{O}$ record from Lomonsovfonna ice core, Svalbard [21], e winter (DJF) NAO Index [19], f MIZ\% from the core NP16-Kro1-MCB, g spatially averaged April Sea ice extent anomalies from Greenland Sea [10], h fram strait Sea ice extent (1979-2018) [44] 
correspond very well with each other (Fig. 7c). The rising aSSTs in Krossfjorden generally follow the summer SAT record (MOSJ-ICE reports) [52] showing the profound warming trend. The higher communality of increasing Arctic (open water) diatoms and decreasing MIZ diatoms clearly indicate that the background warming observed throughout the Arctic has influenced the local climate in Krossfjorden. The overall increase in SST, SAT and decrease in sea ice conditions are also similar to the longterm variability of annual mean temperature, salinity and ice conditions observed from Grønfjorden, Svalbard, with atmosphere and ocean surface temperatures increasing approximately $2{ }^{\circ} \mathrm{C}$ and $1{ }^{\circ} \mathrm{C}$, respectively, from 1970 to 2007 , and increasingly late dates for first ice and stable land fast ice formation from 1974 to 2008 [67]. The prolonged open-water conditions (reduced sea ice extent) implied by our reconstructions might suggest the ocean surface-atmosphere interactions have an important influence on conditions in the inner fjords of Svalbard. Increasingly since 1981, sea ice covers in major fjords in Svalbard have observed to be decreasing, sometimes with virtually no sea ice during some winter seasons [16]. The decreasing sea ice/snow amplifies the surface ocean warming in the Arctic, as shown by the ERA-Interim reanalysis by Screen and Simmonds [53], contributing to warming throughout the year in the lowermost part of atmosphere.

Our reconstructed ocean surface records also show some similarity with the North Atlantic Oscillation (NAO) over the last 60 years (Fig. 7e) [23]. The winter NAO (December-January-February or DJF) index, from 1950 to 1970 oscillated between negative and neutral values coinciding with colder and more stable reconstructed aSSTs in Krossfjorden. Subsequently during the late 1980's and early 1990's, the more positive NAO index correlates well with the increase in reconstructed aSST.

The net radiative forcing in Svalbard is influenced by levels of $\mathrm{CO}_{2}$ and cloud cover, both of which have increased in recent decades. The increasing $\mathrm{SW}_{\text {down }}$ during summer and increasing $\mathrm{LW}_{\text {up }}$ during winter have recently prolonged the melt seasons in summer and winter, respectively. The radiative forcing has caused the annual mean temperature in Ny-Ålesund to increase by $+1.3 \pm 0.7^{\circ} \mathrm{C} /$ decade, from 1992 to 2012 [35, 36]. Altogether this supports the increase in summer ocean surface temperatures and decrease in sea ice cover captured in our reconstructions. We suggest that the positive feedback mechanisms, as the result of decreasing sea ice and increasing openwater conditions in the region, have caused the overall warming trend in Krossfjorden over the last 60 years, with contributions from atmospheric forcing (due to increasing $\mathrm{CO}_{2}$ level) with positive NAO conditions possibly amplifying the local warming trend.

\section{Conclusions}

The first diatom-based high-resolution paleoceanographic reconstructions of SST and sea ice from Krossfjorden, Svalbard show variations in ocean surface conditions from 1953 to 2014. The records indicate the trends of warming aSST $\left(0.6{ }^{\circ} \mathrm{C}\right.$ from the record $)$ and decreasing sea ice for Krossfjorden. The reconstructions agree well with various available regional instrumental records for the magnitudes of multidecadal trends and observed decadal scale features such as the cold period from 1950 to 1970 in Svalbard and accelerated warming post 2006 . We propose that the warming trend of ocean surface temperatures reconstructed in Krossfjorden is in part a response to the general background warming in the Arctic, resulting in more open-water conditions and shorter sea ice cover, inducing a positive ice-albedo feedback. The dominance of Arctic Water diatoms and MIZ diatoms show an overall pattern of increasing aSST and open-water conditions in Krossfjorden from 1953 to 2014. Contributions from increasing radiative forcing over the study period coupled with the prevalent atmospheric circulation could have amplified the local warming trend. The shift from glacier-proximal to ice-free conditions are a distinct characteristic of many high-Arctic fjords for the late Holocene [45], which provide the baseline for future climate change.

Acknowledgements We would like to thank the cruise leader Katrine Husum of NPI MoSJ-ICE 2016 cruise, and the captain and crew of RV Lance for assisting in sediment coring. This work was funded by the Research Council of Norway (Grant no. 248776/E10) and Ministry of Earth Science, Earth System Science Organization (MoES/Indo-Nor/ PS-2/2015), through the OCTEL project. We thank Svetlana Divina for grain size distribution analysis and Katrine Husum for her valuable inputs. Harikrishnan Guruvayoorappan and Rahul Mohan would also like to thank the Director of National Centre for Polar and Ocean Research (NCPOR) for his constant encouragement and support to our project. This is NCPOR contribution No. J-44/2019-20.

\section{Compliance with ethical standards}

Conflict of interest On behalf of all authors, the corresponding author states that there is no conflict of interest.

\section{References}

1. Andersen C, Koc N, Jennings A, Andrews J (2004) Non uniform response of the major surface currents in the Nordic Seas to insolation forcing: implications for the Holocene climate variability. Paleoceanography 19:PA2003. https://doi. org/10.1029/2002PA000873

2. Andersen C, Koc N, Moros M (2004) A highly unstable Holocene climate in the subpolar North Atlantic: evidence from diatoms. Quat Sci Rev 23:2155-2166 
3. Berner KS, Koc N, Divine D, Godtliebsen F, Moros M (2008) A decadal-scale Holocene sea surface temperature record from the subpolar North Atlantic constructed using diatoms and statistics and its relation to other climate parameters. Paleoceanography 23:PA2210. https://doi.org/10.1029/2006PA001339

4. Berner KS, Koc N, Godtliebsen F, Divine D (2011) Holocene climate variability of the Norwegian Atlantic Current during high and low solar insolation forcing. Paleoceanography 26:PA2220. https://doi.org/10.1029/2010pa002002

5. Burman P (1989) A comparative study of ordinary cross-validation, v-fold cross-validation, and the repeated learning-testing methods. Biometrika 76:503-514

6. Bronk Ramsey C (2008) Deposition models for chronological records. Quat Sci Rev 27:42-60

7. Bronk Ramsey C (2009) Bayesian analysis of radiocarbon dates. Radiocarbon 51:337-360

8. Caissie BA (2012) Diatoms as Recorders of Sea Ice in the Bering and Chukchi Seas: proxy development and application. Dissertation, University of Massachusetts

9. Cottier FR, Nilsen F, Inall ME, Gerland S, Tverberg V, Svendsen $\mathrm{H}$ (2007) Wintertime warming of an Arctic shelf in response to large-scale atmospheric circulation. Geophys Res Lett 34:L10607. https://doi.org/10.1029/2007g1029948

10. Divine DV, Dick C (2006) Historical variability of sea ice edge position in the Nordic Seas. J Geophys Res 111:C01001. https:// doi.org/10.1029/2004JC002851

11. Ebbesen H, Hald M, Eplet TH (2007) Lateglacial and early Holocene climatic oscillations on the western Svalbard margin, European Arctic. Quat Sci Rev 26:1999-2011

12. Elverhøi A, Liestøl O, Nagy J (1980) Glacial erosion, sedimentation and microfauna in the inner part of Kongsfjorden, Spitsbergen. Nor Polarinst Skr 172:33-61

13. Elverh $\varnothing i$ A, Lønne $\varnothing$, Seland R (1983) Glaciomarine sedimentation in a modern fjord environment, Spitsbergen. Polar Res 1:127-149. https://doi.org/10.3402/polar.v1i2.6978

14. Forwick M, Laberg JS, Vorren TO, Jernas P (2015) Quaternary geology and geomorphology, fjord bathymetry and geology. In: Dallmann WK (ed) Geoscience atlas of Svalbard. Norwegian Polar Institute Report Series, vol 148, Norwegian Polar Institute, Tromsø. pp 53-88

15. Førland EJ, Benestad Rasmus, Hanssen-Bauer I, Haugen JE, Skaugen TE (2011) Temperature and precipitation development at Svalbard 1900-2100. Adv Meteorol. https://doi. org/10.1155/2011/893790

16. Gjelten HM, Nordli $\varnothing$, Isaksen K, Førland EJ, Sviashchennikov PN, Wyszyński P, Prokhorova UV, Przybylak R, Ivanov BV, Urazgildeeva AV (2016) Air temperature variations and gradients along the coast and fjords of western Spitsbergen. Polar Res 35:29878. https://doi.org/10.3402/polar.v35.29878

17. Hagen JO, Liestøl O, Roland E, Jørgensen T (1993) Glacier Atlas of Svalbard and Jan Mayen.: Norsk Polarinstitutt. Norsk PolarinstituttMeddelelser (129) UiO

18. Hald M, Ebbesen H, Forwick M, Godtliebsen F, Khomenko L, Korsun S, Olsen L, Vorren T (2004) Holocene paleoceanography and glacial history of the West Spitsbergen area, Euro-Arctic margin. Quat Sci Rev 23:2075-2088

19. Hansen J, Ruedy R, Sato M and Lo K (2010) Global surface temperature change. Rev Geophys 48:RG4004. https://doi. org/10.1029/2010RG000345

20. Hegseth EN, Tverberg V (2013) Effect of Atlantic water inflow on timing of the phytoplankton spring bloom in a High Arctic fjord (Kongsfjorden, Svalbard). J Mar Syst 113-114:94-105

21. Holdsworth G, Ponrchet M, Prantl FA, Meyerhof DP (1984) Radioactivity levels in a firm core from the Yukon Territory, Canada. Atmos Environ 18(2):461-466
22. Howe JA, Moreton SG, Morris C, Morris P (2003) Multibeam bathymetry and the depositional environments of Kongsfjorden and Krossfjorden, western Spitsbergen, Svalbard. Polar Res 22:301-316. https://doi.org/10.1111/j.1751-8369.2003.tb00114.x

23. Hurrell J, National Center for Atmospheric Research Staff (eds) (2018) The Climate Data Guide: Hurrell North Atlantic Oscillation (NAO) Index (station-based). https://climatedataguide.ucar. edu/climate-data/hurrell-north-atlantic-oscillation-nao-index-stati on-based

24. Husum K, Howe J, Baltzer A, Forwick M, Jensen M, Jernas P, Korsun S, Miettinen A, Mohan R, Morigi C, Myhre PI, Prins M, Skirbekk K, Sternal B, Boos M, Dijkstra N, Troelstra S (2019) The marine sedimentary environments of Kongsfjorden, Svalbard: an archive of polar environmental change. Polar Res. https://doi. org/10.33265/polar.v38.3380

25. Intergovernmental Panel on Climate Change (IPCC) (2007) Climate Change 2007: The Scientific Basis. Contribution of Working Group I to the Fourth Assessment Report of the Intergovernmental Panel on Climate Change, edited by S. Solomon et al., Cambridge University Press, New York

26. Isaksson E, Divine D, Kohler J, Martma T, Pohjola V, Motoyama $\mathrm{H}$, Watanabe O (2005) Climate oscillations as recorded in Svalbard ice core d180 records between 1200-1997 AD. Geogr Ann Ser A 87(1):203-214

27. Jernas P, Klitgaard-Kristensen D, Husum K, Wilson L, Koc N (2013) Palaeoenvironmental changes of the last two millennia on the western and northern Svalbard shelf. Boreas 42:236-255

28. Jiang H, Seidenkrantz M-S, Knudsen K, Eríkssons J (2002) LateHolocene summer sea-surface temperatures based on a diatom record from the north Icelandic shelf. Holocene 12:137-147

29. Justwan A, Koc N, Jennings AE (2008) Evolution of the Irminger and East Icelandic Current systems through the Holocene, revealed by diatom-based sea surface temperature reconstructions. Quat Sci Rev 27:1571-1582

30. Kim M, Jung JY, Laffly D, Kwon HY, Lee YK (2017) Shifts in bacterial community structure during succession in a glacier foreland of the High Arctic. FEMS Microbiol Ecol 93:1-9

31. Koc N, Jansen E, Haflidason H (1993) Paleoceanographic reconstructions of surface ocean conditions in the Greenland, Iceland and Norwegian seas through the last $14-\mathrm{Ka}$ based on diatoms. Quat Sci Rev 12:115-140

32. Koc N, Karpuz N, Schrader H (1990) Surface sediment diatom distribution and holocene paleotemperature variations in the Greenland, Iceland and Norwegian Sea. Paleoceanography 5:557-580

33. Kumar P, Pattanaik JK, Khare N, Balakrishnan S (2018) Geochemistry and provenance study of sediments from Krossfjorden and Kongsfjorden, Svalbard (Arctic Ocean). Polar Sci 18:72-82. https://doi.org/10.1016/j.polar.2018.06.001

34. Ligowski R, Godlewski M, Łukowski A (1992) Sea ice diatoms and ice edge planktonic diatoms at the northern limit of the Weddell Sea pack ice. Polar Biol 5:9-20

35. Maturilli M, Herber A, König-Langlo G (2013) Climatology and time series of surface meteorology in Ny-Ålesund, Svalbard. Earth Syst Sci Data 5:155-163. https://doi.org/10.5194/essd-5-155-2013

36. Maturilli M, Herber A, König-Langlo G (2014) Surface radiation climatology for Ny Ålesund, Svalbard (78.9 N), basic observations for trend detection. Theor Appl Climatol 120:331. https:// doi.org/10.1007/s00704-014-1173-4

37. Meslard F, Bourrin F, Many G, Kerhervé P (2018) Suspended particle dynamics and fluxes in an Arctic fjord (Kongsfjorden, Svalbard) Estuarine. Coast Shelf Sci 204:212-224. https://doi. org/10.1016/j.ecss.2018.02.020

38. Miettinen A (2018) Diatoms in Arctic regions: potential tools to decipher environmental changes. Polar Sci 18:220-226 
39. Miettinen A, Divine D, Koc N, Godtliebsen F, Hall IR (2012) Multicentennial variability of the sea surface temperature gradient across the subpolar North Atlantic over the last $2.8 \mathrm{kyr}$. J Clim 25:4205-4219

40. Miettinen A, Divine DV, Husum K, Koc N, Jennings A (2015) Exceptional ocean surface conditions on the SE Greenland shelf during the medieval climate anomaly. Paleoceanography 30:1657-1674

41. Muckenhuber S, Nilsen F, Korosov A, Sandven S (2016) Sea ice cover in Isfjorden and Hornsund, Svalbard (2000-2014) from remote sensing data. Cryosphere 10:149-158

42. Nilsen F, Cottier F, Skogseth R, Mattsson S (2008) Fjord shelf exchange controlled by ice and brine production: the interannual variation of Atlantic Water in Isfjorden, Svalbard. Cont Shelf Res 28:1838-1853

43. Nilsen F, Skogseth R, Vaardal-Lunde J, Inall M (2016) A simple shelf circulation model-intrusion of Atlantic water on the West Spitsbergen Shelf. J Phys Oceanogr 46:1209-1230

44. Nuth C, Kohler J, König M, Deschwanden AV, Hagen JO, Kääb A, Moholdt G, Pettersson R (2013) Decadal changes from a multitemporal glacier inventory of Svalbard. Cryosphere. ISSN 19940416. 7(5):s 1603-1621. https://doi.org/10.5194/tc-7-1603

45. Oksman M, Weckstrom K, Miettinen A, Ojala AEK, Salonen VP (2017) Late Holocene shift towards enhanced oceanic variability in a High Arctic Svalbard fjord $\left(79^{\circ} \mathrm{N}\right)$. Arktos 3:4. https://doi. org/10.1007/s41063-017-0032-9

46. Oksman M, Juggins S, Miettinen A, Witkowski A, Weckström K (2019) The biogeography and ecology of common diatom species in the northern North Atlantic, and their implications for paleoceanographic reconstructions. Mar Micropaleontol 148:1-28. https://doi.org/10.1016/j.marmicro.2019.02.002

47. Orme LC, Miettinen A, Divine D, Husum K, Pearce C, van Nieuwenhove N, Born A, Mohan R, Seidenkrantz M-S (2018) Subpolar North Atlantic sea surface temperature since 6 ka BP: indications of anomalous ocean-atmosphere interactions at 4-2 ka BP. Quat Sci Rev 194:128-142

48. Pavlov AK, Tverberg V, Ivanov BV, Nilsen F, Falk- Petersen S, Granskog MA (2013) Warming of Atlantic water in two west Spitsbergen fjords over the last century (1912-2009). Polar Res 32:11206. https://doi.org/10.3402/polar.v32i0.11206

49. Pinglot J-F, Pourchet M, Lefauconnier B, Hagen JO, Isaksson E, Vaikmäe R, Kamiyama K (1999) Investigations of temporal change of the accumulation in Svalbard glaciers deducted from nuclear tests and Chernobyl reference layers. Polar Res 18(2):315-321

50. Piquet AMT, van de Poll WH, Visser RJW, Wiencke C, Bolhuis H, Buma AGJ (2014) Springtime phytoplankton dynamics in Arctic Krossfjorden and Kongsfjorden (Spitsbergen) as a function of glacier proximity. Biogeosciences 11:2263-2279

51. Polyak L, Alley RB, Andrews JT, Brigham-Grette J, Cronin TM, Darby DA, Dyke AS, Fitzpatrick JJ, Funder S, Holland M, Jennings AE, Miller GH, O'Regan M, Savelle J, Serreze M, St. John K, White JWC, Wolff E (2010) History of sea ice in the Arctic. Quat Sci Rev 29:1757-1778

52. Renner AHH, Dodd PA, Fransson, A (2018) An assessment of MOSJ: the state of the marine climate system around Svalbard and Jan Mayen, Norwegian Polar Institute, Troms $\varnothing$ (Report series/ Norwegian Polar Institute; no 048)

53. Screen JA, Simmonds I (2010) The central role of diminishing sea ice in recent Arctic temperature amplification. Nature. https://doi. org/10.1038/nature09051
54. Schrader HJ, Gersonde R (1978) Diatoms and Silicoflagellates. Micropaleontological counting methods and techniques-an exercise on an eight meters section of the lower Pliocene of Capo Rossello. Utrecht Micropaleontol Bull 17:129-176

55. Solomon $\mathrm{S}$ et al (eds) Climate change (2007) The physical science basis. Cambridge University Press, Cambridge

56. Slubowska M, Koc N, Rasmussen T, Klitgaard-Kristensen D (2005) Changes in the flow of Atlantic water into the Arctic Ocean since the last deglaciation: evidence from the northern Svalbard continental margin, $80^{\circ} \mathrm{N}$. Paleoceanography 20:PA4014. https:// doi.org/10.1029/2005pa001141

57. Slubowska-Wodengen M, Rasmussen TL, Koc N, Klitgaard- Kristensen D, Nilsen F, Solheim A (2007) Advection of Atlantic Water to the western and northern Svalbard shelf since $17,500 \mathrm{cal}$ yr BP. Quat Sci Rev 26:463-478

58. Spielhagen RF, Werner K, Sørensen SA, Zamelczyk K, Kandiano E, Budeus G, Husum K, Marchitto TM, Hald M (2011) Enhanced modern heat transfer to the Arctic by Warm Atlantic Water. Science 331:450-453

59. Streuff K, Forwick M, Szczuciński W, Andreassen K, ÓCofaigh C (2015) Submarine landform assemblages and sedimentary processes related to glacier surging in Kongsfjorden, Svalbard. Arktos 1:14. https://doi.org/10.1007/s41063-015-0003-y

60. Svendsen H, Beszczynska-Moller A, Hagen JO, Lefauconnier B, Tverberg V, Gerland S, Orbaek JB, Bischof K, Papucci C, Zajaczkowski M, Azzolini R, Bruland O, Wiencke C, Winther JG, Dallmann W (2002) The physical environment of Kongsfjorden-Krossfjorden, an Arctic fjord system in Svalbard. Polar Res 21:133-166

61. ter Braak CJF, Juggins S (1993) Weighted averaging partial leastsquares regression (WA-PLS) — an improved method for reconstructing environmental variables from species assemblages. Hydrobiologia 269:485-502

62. Trachsel M, Telford RJ (2016) Technical note: estimating unbiased transfer-function performances in spatially structured environments. Clim Past 12:1215-1223

63. Tverberg V, Nøst OA, Lydersen C, Kovacs KM (2014) Winter sea ice melting in the Atlantic Water subduction area, Svalbard Norway. J Geophys Res 119(9):5945-5967. https://doi. org/10.1002/2014jc010013

64. Vihtakari M (2019) PlotSvalbard: PlotSvalbard—plot research data from Svalbard on maps. R package version 0.8.5. https:// github.com/MikkoVihtakari/PlotSvalbard

65. von Quillfeldt C, Ambrose W, Clough L (2003) High number of diatom species in first-year ice from the Chukchi Sea. Polar Biol 26:806-818

66. Werner K, Spielhagen RF, Bauch D, Hass HC, Kandiano E (2013) Atlantic Water advection versus sea-ice advances in the eastern Fram Strait during the last $9 \mathrm{ka}$ : multiproxy evidence for a twophase Holocene. Paleoceanography 28:283-295

67. Zhuravskiy D, Ivanov B, Pavlov AI (2012) Ice conditions at Gronfjorden Bay, Svalbard, from 1974 to 2008. Polar Geogr 35:169_ 176. https://doi.org/10.1080/1088937x.2012.662535

Publisher's Note Springer Nature remains neutral with regard to jurisdictional claims in published maps and institutional affiliations. 